\title{
The Tourist-Recreational Potential of the Lipetsk Region: Problems and Prospects
}

\section{Vladimir Nikolaevich Pishchulin}

\author{
Bunin Yelets State University, 399770, Yelets, Lipetsk region, 28 Kommunarov Str., Russian Federation \\ Email: vn_pishchulin@mail.ru
}

Doi:10.5901/mjss.2015.v6n4s4p260

\begin{abstract}
The article considers the problem of the tourist and recreational potential of Lipetsk Region. Tourism development, acting as a tool for wellness of the nation, contributes to reproduction of human capital, plays an important role in solving social and economic problems, in creating additional jobs in the region. The article provides an assessment of the tourism and recreational potential of Lipetsk Region, highlights the main tourist clusters, problems and prospects of tourism development in the area. In current economic and ecological environment social and demographic situation in the region is exacerbating. Lipetsk region needs breakthrough development in tourism and recreational areas as well as service industry. As the means of increasing the number of tourist arrivals, promotion of national tourist product in the international and domestic tourism markets and further development of tourist and recreational areas of Lipetsk region, the article suggests further capital construction and modernization of tourism infrastructure; subsidization of loan interest rates; development of training and retraining system; using innovative technologies in the field of tourist services quality management; creating an integrated automated information system to support development of inbound and domestic tourism, placing information and image materials and programs on tourism opportunities in Russia as a whole and the region in particular; implementation of a further event to promote the tourism product in the region of Russia and in foreign countries; and also hold business conferences, forums and exhibitions on constituent territory of the Russian Federation. Implementation of above mentioned measures will allow effective tourism development in Lipetsk region which is sufficient for human capital reproduction.
\end{abstract}

Keywords: tourist-recreational potential, expanded reproduction, human capital, tourism development, main tourism clusters.

\section{Introduction}

Currently, recognition of the place and role of a man in the process of social reproduction heightened the interest in formation and use of its human capital. In modern information society with its high-tech economy industrial efficiency is critically dependent on the state of human resources. However, social and economic, demographic and political changes significantly impair quality of life and health of population, which raises alarm. In this respect one of the main directions of transition towards innovative socially-oriented type of economic development in Russia is to create conditions to improve quality of life of Russian citizens. Measures that increase reproduction are of high priority.

The Russian Federation possesses great natural, historical and cultural, scientific and educational potential, which can ensure human capital reproduction providing it is effectively used. So what is a 'reproduction of human capital'?

This research aims at studying the problems of the tourism potential of Lipetsk region. Tourism development, acting as a tool for improvement of the nation, contributes to the reproduction of human capital, plays an important role in solving social and economic problems, creates additional jobs in the region. This study provides a detailed assessment of the tourism potential of the Lipetsk region, highlights the main tourist clusters, devoted to the problems and prospects of tourism development in the region.

\section{Literature Review}

This section discusses in detail the concept of 'labor', 'reproduction of labor power', 'reproduction of capital', 'simple reproduction', 'expanded reproduction', 'constricted reproduction', gives different definitions of 'human capital' and considers previous studies on the reproduction of human capital.

\subsection{Simple, expanded and constricted reproduction}

At first attention should be turned to the definition of 'reproduction of capital'. Under reproduction in economy we 
understand continuous iterative production process, distribution and exchange of economic goods, which includes reproduction of tangible elements of the system, industrial relations between them and reproduction of labor power. According to the nature of resources use one can distinguish simple, expanded and constricted reproduction. Simple reproduction is repetition of the production process unabated, expanded reproduction is repetition of the production process in the larger size, as part of the revenue is used to purchase additional resources through the use of which production is resumed on a larger scale. Constricted reproduction is repetition of the production process at a reduced level due to lack of income or inappropriate development of this type of production.

\subsection{Extended reproduction in classical political economy and Marxist doctrine}

In the subsidy-oriented economy, it is necessary to talk about expanded labor power reproduction. Expanded labor power reproduction is a complex scientific issue, combining conceptual provisions of classical political economy (Adam Smith, David Ricardo, Jean-Baptiste Say), the Marxist doctrine (reproduction as a prerequisite for the mankind existence, and as a backbone factor considered as consolidated reproduction of material goods, labor and industrial relations), and others (Smith, 1956).

\subsection{The modern concept of 'human capital'}

At present, in economics the concept of expanded reproduction of labor is associated with the concept of 'human capital'. In its interpretation the human capital is defined as a special type of investment, the total cost of the development of the reproductive potential of the person, improving quality and enhancing the overall performance of the labor force (Mayburov, 2004).

\subsection{Need for creation and development of tourist and recreational sphere}

Natural and acquired human capital under the influence of scientific and technological progress is subject to accelerated wearing. Intensive and unsustainable exploitation of human capital reduces physical potential of employees and at the same time increases cost of its maintenance. Accumulation of intellectual potential of the workers also depends on their health status. To eliminate accumulated physical fatigue, reduction of mental stress occurring in labor process, to eliminate the adverse effects of the environment one requires the allocation of time to rehabilitate or conduct recovery procedures. This kind of holiday should be considered as a mandatory element for the human capital reproduction, which determines creation of industries for the restoration of labor potential. All of this requires systematic development of the tourism and recreational sector. However, ongoing social and economic changes impair the quality of life and health of the population, leading to a crisis of demographic situation, major challenges in economic complex, which, in turn, hinders intensive economic development of the country. To create conditions for improving quality of life of the Russian citizens through the development of infrastructure, tourism and recreation, as well as to ensure quality, availability and competitiveness of tourist services is currently one of the main lines of transition to innovative socially-oriented type of economic development of Russia.

\subsection{Definition of human capital reproduction}

Thus, reproduction of the human capital should be understood as the process of formation and development of specific human resources, which is carried out through investments in specific processes of the individual's activity. At the same time investments in human capital can be regarded from the perspective of financial investment funds as well as stockpiling and abilities as a result of certain processes, developing human capital - education, training, health promotion and prevention, health care, improved housing conditions, etc. This article will focus on the human capital investment in the sphere of tourism.

\section{Research Methodology}

\subsection{Analysis of the current state of Russian tourism market}

The analysis of the current state of the Russian tourism market shows that in general its development is stable and dynamic. Annual growth of the internal tourist flow and revenues from tourism is reported. In 2013, according to the 
Federal Agency for Tourism of the Russian Federation, the share of tourism in the country's GDP was 2.5\%, the share of tourism revenues in the GDP, taking into account the multiplier effect reached 6.5\%. At the same time, these figures are far behind the countries with developed tourism industry. For example, in Austria the share of tourism in GDP is 8.6\%, and taking into account the multiplier effect - 15\%; in Spain $6.8 \%$ and $18.2 \%$, respectively, in France $-4.1 \%$ and $10.9 \%$, in Croatia - $8.5 \%$ and $19 \%$, in the UK - 3.4\% and $9.1 \%$ (Pisarevsky, 2013).

Increase in domestic tourist traffic, growth rates of which make $10-12 \%$ or 2-2.5 million people a year, has become a characteristic feature of the recent two years.

Experience of the world's leading countries confirms that health investment is the most effective strategy for economic development. In this regard, domestic tourism and recreation development is one of the factors that have a significant impact on health of the nation.

\subsection{Environmental and demographic situation in Lipetsk region}

Unfavorable ecological situation has developed in Lipetsk region in conditions of intensive development of metallurgical industry. Occupying $0.14 \%$ of the Russian Federation territory, the region accounts for $0.8 \%$ of polluted waste water and for $0.9 \%$ of contaminants. The analysis shows that the main polluter in the region is the city of Lipetsk, and inside the city it is Novolipetsk Steel (NLMK). In 2013 the regional center accounted for 300.6 thousand tons of carbon dioxide emissions into the atmosphere. At the same time, based on the assessment of the existing pollution dynamics pattern as well as production increase in the industrial zones of cities of Lipetsk, Chaplygin and the village of Terbuny, and resulting from implementation of new projects in the livestock sector, increasing application of chemicals in crop production, the environmental situation will continue to deteriorate.

Under the current economic and environmental conditions social and demographic situation in the region exacerbates greatly. In particular, the population incidence rate in the region at large has been steadily growing: whereas in 1990 throughout the year 764 thousand of people suffered from various diseases, in 2010 the number of cases rose to 812.2 , or by $12.7 \%$, with simultaneous reduction of the population of the region during this period from 1231.4 to 1163.3 thousand persons, or 5.5\%. The death rate per thousand of population, which amounted to 12.8 in 1990, reached 17.0 people in 2010, natural decline increased from 0.7 to 6.8 per 1,000 inhabitants (Russia in Figures, 2011). Under these circumstances, formation of recreation health system becomes objectively necessary. One of the main components of this system is to develop tourism potential of the region.

\section{Discussion}

Federal Agency for Tourism (Rosturizm) currently creates favorable conditions for the development of tourism and recreation industry in Russia's regions, including implementation of programs and projects in the field of public and private partnership.

\subsection{Evaluation of the tourism and recreational potential of Lipetsk region}

Lipetsk Region distinguishes itself among the other regions of the Central Federal District by favorable geographical location, huge historical, cultural, natural resources and has a variety of tourism and recreational potential, which allows developing various types of tourism, able to meet a wide range of consumer demand.

In recent years, Lipetsk Region significantly intensified its efforts to promote tourism and recreational potential as a cultural and tourist center, as well as an investment attractive object that is actively strengthening its position in the international and inter-regional communication systems. The region has a high potential for development of various forms of civilized tourism: historical, cultural, educational, religious and environmental ones. The region has certain potential in the field of cultural and leisure recreation. The area has four professional theaters, which in 2013 were visited by 168.2 thousand spectators, 26 museums, 491 establishments of cultural and leisure and 520 public libraries. There is significant passenger transportation in the region, but their value in terms of transportation rates growth declined in 2010 by $55 \%$ compared to 2000 and amounted to 159.1 million persons. The region has considerable opportunities to provide tourists with motor transport and servicing (Nechaev, 2007).

\subsection{Ecological agrarian tourism as an integrated universal product}

The region has developed agriculture, its traditional lines of production being cereals, sugar beets, potatoes, poultry, pig 
farming, cattle ranching, and others. The latter gives an opportunity to develop environmentally friendly production, and in places for recreation as well. Despite gradual increase in the regional agribusiness production volume emerging in the last decade and greater attention to the problems of rural areas of the state, living standards of the rural residents are still low.

One of the most important lines in solving this problem is the development of alternative types of business in Lipetsk Region, in particular of ecological agrarian tourism, based on the use of agricultural, natural, cultural, historical and other resources of the countryside and its specificity to create an integrated tourist product. Agritourism is a comprehensive universal product which complements and combines different types of tourism: ecological, adventure, sports, cultural, educational, gastronomic and others.

Development of tourist destinations in Europe began more than 30 years ago and agritourism is most actively developing there. Thus, in 2013 in France there were 35000 farms with mini-hotels and inns, in Germany there were 20 000 places with hotels, in Italy about 10000 farms with hotels, in England - farms with hotels for 120000 accommodations. During the period in question in the Apennine peninsula more than 12000000 people had a rest in agricultural farms. In Western Europe about 40000000 citizens preferred agrarian tourism to the resorts. Overall in Europe annual growth of agrarian tourism makes $10 \%$.

In many regions of Russia agritourism has been actively developed. At the same time, this niche is still not occupied completely, and therefore tourist industry experts predict unprecedented success of the industry. Such is the Central Black Earth economic region in general and Lipetsk region in particular. The area of Central Black Earth region is 166.8 thousand sq. $\mathrm{km}$, with a population of 7800 thousand people, $60 \%$ of them being urban residents. Tired of urban lifestyle, man-made loads and loads upon nervous system, an urban man requires rehabilitation. To reduce negative factor impact on health, to distract from daily routine, is possible by making use of such recreation activities as agrarian tourism.

Currently, Lipetsk Region, possessing a significant number of archaeological, historical, architectural and art monuments has established infrastructure, which may be involved in tourism. Spa treatment and recreation in the region have long stable tradition. Favorable climate, coniferous and deciduous forests, endless fields, rivers, lakes and ponds, picturesque hills, limestone cliffs and caves, ecologically clean areas are an important condition for the development of agrarian tourism.

\subsection{Current state of tourism infrastructure in Lipetsk Region}

At the same time there is a number of factors hindering development of tourism in the area. Lipetsk Region has insufficient basis for spa services and leisure travelers. Whereas there are 31.6 beds per 10,000 inhabitants nationwide in sanatoriums, treatment sanatoriums and rest homes and in recreation organizations of Russia this figure totals to 20.8, in Lipetsk Region the corresponding figures are 30.5 and 18.0. The quantity and quality of placements does not create facilities for active tourism. In total turnover of retail trade area hotel and restaurant business takes insignificant place of $0.4 \%$, and transport and communication services make $0.8 \%$. In 201335 organizations of hotel type with a capacity of 2.02 thousand of people operated in Lipetsk Region. Their services have been used by 105,700 people. Proceeds from the stay were RUB 201.9 million, which leads to the fact that chargeable tourist services in the structure of the services provided to the population make RUB 300.7 million or $1.4 \%$ of the total volume. According to the territorial body of the Federal State Statistics Service, supply for hotels in Lipetsk Region was 1.47 rooms per 1,000 inhabitants. For comparison, in Moscow this figure is 1.88 rooms, in St. Petersburg - 2.87 rooms. As specialists forecast, supply for hotels in Lipetsk Region will increase to 2.25 rooms per 1,000 inhabitants in 2015 (Tourism Figures 2013).

Unfortunately, region passenger transportation by civil aviation is underdeveloped. In 2000, 6.4 thousand people were transported by air and in 2010 there were 15.0 thousand passengers. Bus availability currently remains low, being about $86.6 \%$, and the release rate of buses on the line is $72.7 \%$. This is due to the fact that the majority of companies and individual entrepreneurs acquire morally obsolete foreign buses. In general, it should be recognized that in Lipetsk Region breakthrough development of service industries is necessary. It is this breakthrough that will enable recreation development in the region. In turn, this implies a sharp increase in investment of all participants of economic activity.

\subsection{Development of tourism clusters in Lipetsk region}

Currently, Lipetsk Region has been included in the Federal Target Program "Development of Domestic Tourism in the Russian Federation (2011-2018 years)". In order to increase competitiveness of domestic tourism market the federal target program envisages creation of tourism clusters - concentration of businesses and organizations involved in 
development, production, promotion and marketing of the tourist product as well as activities adjacent to the tourism and recreational services within a limited area. Tourism cluster is a consolidated investment project consisting of functionally, organizationally, financially related projects on building tourist and providing infrastructure within single territory. Tourism and recreation cluster brings together companies and organizations of tourism as well as related services which complement each other, and share recreational potential of the territory.

In terms of the Program in question, two clusters have been created in Lipetsk Region: auto tourist cluster "Zadonshchina" and tourist-recreational cluster "Elets" accommodated in Zadonsk and Yelets. In 2013 three more clusters were formed in order to include them in the list of activities of the Federal Target Program. One of them, auto tourist cluster "Oranienburg", is located in Chaplyginsky district and two tourist-recreational clusters "Dobriy" and "Shukhovskyy" are located in Dobrovsky and Dankovsky districts of Lipetsk Region.

\subsection{Tourist resource structure of the city of Yelets}

Tourist resource structure of the city of Elets is compared with the trends that function in world tourism and suggests the need for its prior development in cultural, religious, Orthodox, health tourism and leisure as well as business tourism areas. For cities like Elets tourism can become one of the leading factors in social and economic development. In a city with well-developed industry, urban and municipal cultural institutions network and service, system of tourism enterprises should take into account these factors.

It should be noted that the projects of special economic zones of regional level of tourist-recreational type (SEZ TRT) "Elets" and "Zadonshchina" have been implemented since 2006. In the next three years RUB 4 billion from all sources of funding will be invested in development of tourist potential of special economic zones "Elets" and "Zadonshchina", which is a huge investment in the development of the region and creation of new jobs.

While implementing the measures of the project for creation of the tourist clusters in Lipetsk Region, there is a unique opportunity in the framework of public-private partnerships to share the burden of investment inflows with the state, which, in turn, will enable to:

- Use mechanism for subsidizing interest rates on loans taken for tourist and recreational use from the Russian credit organizations with a long payback period;

- To provide an intensive growth of tourists through deployment of public awareness campaigns, organization and conducting of exhibitions, forums and other events.

Investment project implementation will allow reducing average payback period, ensuring profitability increase of investment projects, including due to synergies in the development of related fields. It is planned that by creating clusters "Elets", "Zadonshchina", "Oranienburg", "Dobriy" and "Shukhovskyy" the number of tourists and businessmen who come to the region will grow by five times, and in turn a need to build new facilities of the tourist industry will arise.

\subsection{Preferences of special economic zones participants}

Since clusters are located in the territory of SEZ TRT "Elets" and "Zadonshchina", while becoming a party to the abovementioned zones the investor also receives a number of preferential benefits at the regional level:

- tax exemption for organizations in respect of property taken into account on the balance sheet of SEZ TRT participant organization for the period of 7 years from the time of registration;

- vehicle tax rebate for the SEZ TRT participant organization in respect of vehicles taken into account on balance of the SEZ TRT participant organization, for the period of 10 years from the time of vehicle registration;

- $\quad$ tax rebate subject to crediting in favor of regional budget by 4 percentage points of income in respect of profits derived from investment project in the territory of SEZ TRT within 5 years for a SEZ TRT participant;

- rental rate for land provided for the OEZRU TRT participants established during the construction period of not more than $2 \%$ of the cadastral land value;

- land tax rebate for participants of special economic zones at the regional level in respect of the land located in the territory of OEZRU TRT for the period of 3 years in the SEZ TRT "Elets" and for 5 years in the SEZ TRT "Zadonshchina" since emergence of the land ownership title.

\subsection{Activities on further development of tourist and recreational sector in Lipetsk Region}

Therefore, in order to increase the number of tourist arrivals, to promote domestic tourism product in the international and 
domestic tourist markets and to further develop tourism and recreational area of Lipetsk Region it is necessary to solve the following issues:

- capital construction and modernization of supporting infrastructure providing for tourist facilities with long payback periods;

- interest rate subsidies for loans taken by investors of tourism and recreational use from banking institutions of Russia;

- development of training in tourism and hospitality industry;

- improving of tourism industry stuff training and retraining;

- introduction of innovative technologies in the field of tourist services quality management;

- creation of integrated automated information system for complex support of inbound and domestic tourism development;

- creation and placement of information and image materials and programs on tourism opportunities nationwide and in the regions in particular on television, radio stations, urban media, the Internet;

- carrying out activities to promote tourism product of Russia in the territory of foreign states; holding business events (conferences, forums, exhibitions) in the territory of the constituent entities of the Russian Federation.

In general, implementation of investment projects will allow reducing average payback period; ensuring increased profitability of investment projects, including due to synergy in the development of related industries.

Solution of the above tasks will enable future effective development of tourism industry in Lipetsk Region which is extensively capable of human capital reproduction.

\section{References}

Kontseptsiya federalnoy tselevoy programmyi «Razvitie vnutrennego i vjezdnogo turizma v Rossiyskoy Federatsii (2011 - 2018 godyi) [The Concept of the Federal Target Program "Development of Domestic Tourism in the Russian Federation (2011 - 2018 years)] (2013). Tourism: law and economics. № 3. (pp. 19-32). [in Russian]

Mayburov, I.A. (2004). Effektivnost investirovaniya i chelovecheskiy kapital v CShA i Rossii [The effectiveness of investment and human capital in the USA and Russia] / Mayburov, I.A. Mirovaya ekonomika i mezhdunarodnyie otnosheniya [World Economy and International Relations]. - No. 4, p. 4 [in Russian]

Nechaev, N.G. (2007). Turistsko-rekreatsionnyie zonyi v sisteme sotsialno-ekonomicheskogo razvitiya regiona [Tourist and recreational zone in the socio-economic development of the region] / Nechaev, N.G, Pishchulin, V.N., Tagintsev, N.F. Gumanitarnyie aspektyi sotsialno-ekonomicheskogo razvitiya Lipetskoy oblasti: Sbornik statey i vyistupleniy. [Humanitarian aspects of economic and social development of Lipetsk region: collection of articles and speeches]. - Elets: Bunin Yelets State University, (pp. 87-89) [in Russian]

Pisarevsky, E.L. (2013). Aktualnyie problemyi gosudarstvennogo regulirovaniya podgotovki kadrov dlya sferyi turizma [Actual problems of state regulation of training for tourism] / Pisarevsky, E.L., Fefelova, V.N. / Tourism: law and economics, No. 2, (pp. 29 - 32).

Rossiya v tsifrakh [Russia by the Numbers]: Short Statistical Book (2011). - Moscow: Rosstat, (p. 581) [in Russian]

Smith, A. (1956). The Wealth of Nations, Moscow: Sotsekgiz, (p. 490) [in Russian]

Travnikov, A.M. (2010). Monitoring investitsionnoy aktivnosti v regionah Rossii v 2010 godu [Monitoring of investment activity in the regions of Russia in 2010] Annual information and analytical report. - Moscow: ANO "NISIP", (p. 26) [in Russian]

Turizm v tsifrakh [Tourism in numbers] (2013), statistics digest I IPC Statistika Rossii, Federalnoe agentstvo po turizmu [Statistics of Russia, Federal Agency for Tourism] - Moscow: IPC "Statistika Rossii", (39 p.) [in Russian] 